\title{
Trials offer way forward for Parkinson's
}

\section{Alison Abbott}

Despite widely reported negative side effects, the results of the first controlled clinical trial using transplants of fetal cells to treat Parkinson's disease are positive for the therapy's long-term prospects, researchers say.

But scientists caution that the trial's design makes it difficult to interpret. Published this month in the New England Journal of Medicine (344, 710-719), the trial was led by Curt Freed of the University of Colorado.

Freed transplanted precursors of dopamine-producing cells from human fetal brains into the brains of 20 patients with severe Parkinson's disease. Twenty other patients received 'sham surgery' in which no cells were transplanted. The transplants survived and produced dopamine, the lack of which causes the disease. The results prove the principle of such transplants for the first time in a controlled study, researchers say. But the reported clinical benefits were modest, and five patients developed severe side effects.

Parkinson's disease is characterized by movement disorders ranging from tremors to full rigidity. It can be treated with L-DOPA, which is converted into dopamine in the brain. But after long-term treatment, most patients start to respond unpredictably. Some become

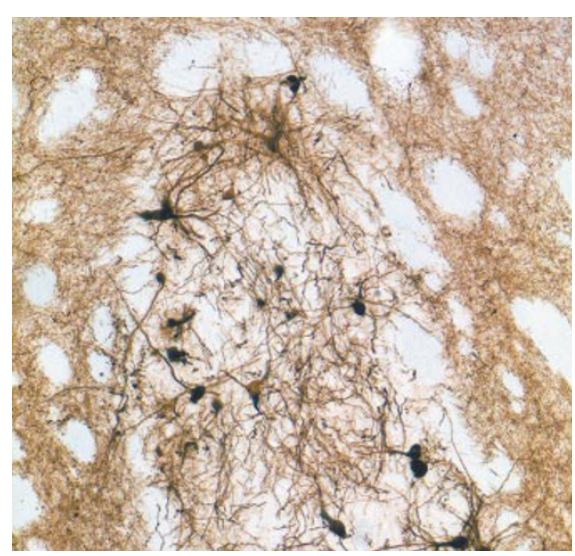

Natural source: fetal tissue transplants can produce dopamine in patients with Parkinson's.

oversensitive to the drug and experience uncontrolled limb movements, or dyskinesias.

The idea of transplanting fetal cells is to boost dopamine levels using a more natural source - human cells. Two US teams have been funded by the National Institutes of Health to conduct controlled trials to test the technique: Freed's is the first, and the second, led by Thomas Freeman of the University of South Florida, will finish next year.

In Freed's trial, five patients developed severe dyskinesias more than a year after the operation, leading to press reports that the trial had gone badly wrong (see The New York Times, 8 March 2001). But Olle Lindvall, a neurologist who pioneered the transplant technique at the University of Lund in Sweden, disputes this interpretation. "Freed's study is important because it has shown for the first time a specific graftinduced response," he says.

Freed says that the dyskinesias might have been caused by overproduction of dopamine. But Lindvall says that there is absolutely no evidence of dopamine overproduction, and that the mechanism remains totally unclear.

Freeman says that Freed's study was also hampered by its subjective primary endpoint, in which patients' progress was assessed by interview one year after surgery. "This was a mistake," concedes Freed, who believes that it underestimated the patients' true clinical improvement.

Researchers in the field agree that any future cell therapy for Parkinson's will have to use cultured cell lines to provide a better source of transplant material. Researchers are also trying to genetically engineer cell lines that will self-destruct after transplantation if severe side effects develop.

\section{Bush U-turns on pledge for carbon dioxide emissions}

\section{Mark Schrope}

In a move that has dashed environmentalists' hopes that the new administration might accommodate their views on global warming, President George W. Bush has reversed a campaign pledge to place mandatory caps on the emission of carbon dioxide from power plants.

In a letter to four senators, Bush attributed his decision to the "incomplete state of scientific knowledge of the causes of, and solutions to, global climate change and the lack of commercially available technologies for removing and storing carbon dioxide".

Bush's action was widely criticized by environmentalists, European government officials and moderate Republicans.

Sherwood Boehlert (Republican, New York), chair of the Science Committee in the House of Representatives, called it “a misguided and unjustified reversal of position".

On 14 March, the day after Bush's announcement, Boehlert's committee held a meeting on climate-change research at which all witnesses testified that greenhouse-gas emissions were contributing to global climate change. Boehlert later said: "I've got some advice for the president: pay attention to the scientific enterprise."

Legislation to amend the Clean Air Act so as to cap carbon dioxide emissions has been proposed by Boehlert and a bipartisan group of congressmen and senators. But it is expected to fail without Bush's support.

Sean McCormack, a Bush administration official, says the administration's approach to climate change is being totally reassessed. "Other parties should not make any assumptions about what US policy will be until the review is complete," he says.
International leaders took the unusual step of commenting on Bush's decision. Margo Wallström, environmental commissioner for the European Union, said in a statement that she was concerned about Bush's characterization of the science of global climate change. And Klaus Toepfer, executive director of the United Nations Environment Programme, said in a speech in Denmark that he doubted there could be an effective global response to climate change without US leadership.

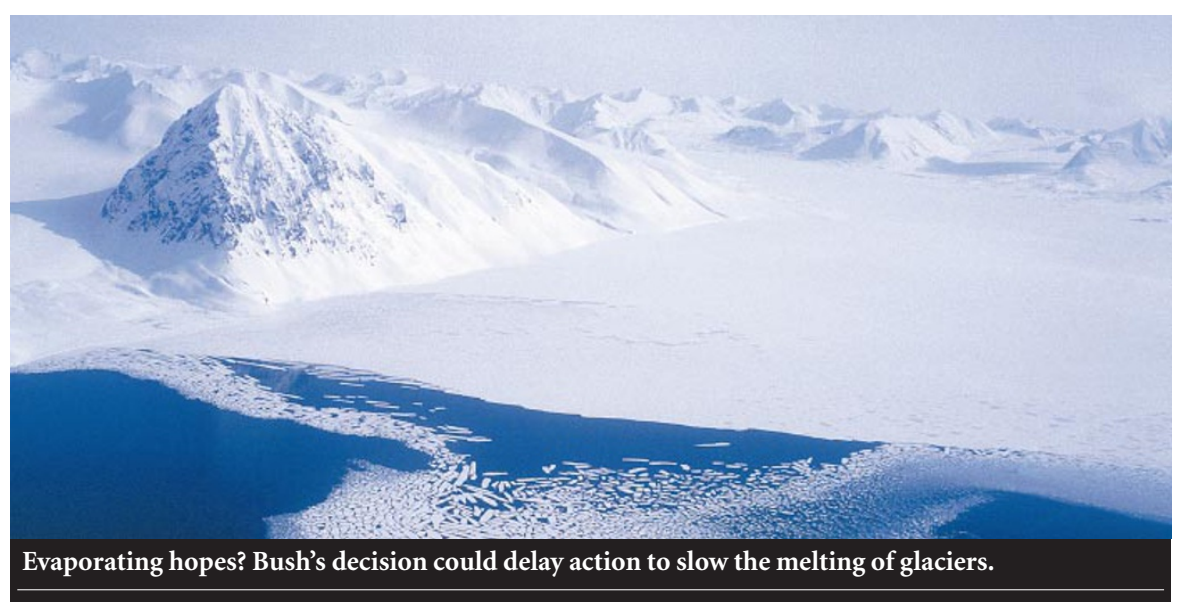

